\title{
The structure, biosynthesis and functions of EPA: biomolecular neuropsychiatric aspects
}

\author{
Sofia Tsaluchidu \\ From $1^{\text {st }}$ International Congress on Neurobiology and Clinical Psychopharmacology and European \\ Psychiatric Association Conference on Treatment Guidance \\ Thessaloniki, Greece. 19-22 November 2009
}

Biochemical, clinical and genetic evidence indicates that in neuropsychiatric disorders the alteration of membrane phospholipids metabolism can play a protogenetic role associated with that of the proportional balance of polyunsaturated fatty acids.

Various PUFA have been experimented with as therapeutic and helpful means of protection in the treatment of neuropsychiatric pathologies. Among these, treatments with pure ethyl-eicosapentaenoic acid (EPA) in double blind clinical studies compared with the placebo have been proved to be more effective. Its biosynthesis starts from alpha-linoleic acid and the activity of the delta- 6 desaturated enzyme.

Ethyl EPA modifies the activity of PLA2, the alteration of which is accompanied by structural changes in neuronal membranes, observed in depressed patients as well as those with Alzheimer's disease. It is enormously important as both precursor to active eicosanoids, which is as capable of competing with AA for the incorporation of the membrane as it is for the substrate according to the so called "fatty acid paradox" for the production of the DHA organism when this is necessary. Such EPA activity, which is crucial for the transmission of interneuronal signals, it interferes of phosphatidyl inositol bisphosphate regulation, linked to the activity of the alpha subunit of the $\mathrm{G}$ protein. The hydrolysis derivates of PIP2 they are the second messenger associated with different neurotransmissional systems and metabolic process. EPA interferes in the process, inhibiting the protein kinase-C AMPc- dependent (PKC). In vitro inhibit the activity of PKC of the protein kinase II Ca2+/calmodulina dependent and inhibit the activation, induced by $5 \mathrm{HT}$, of the protein kinase activated by mithogen (MAPK).The proposed mechanism of pure ethyl EPA as

University of Bologna, Italy the calcium-antagonist, blocking $\mathrm{Ca} 2+$ channels, is confirmed in cardiovascular studies. Blocking calcium channels could reduce the hyperactive signal transduction process.

Finally, EPA inhibits the production of pro-inflammatory cytokines that they are the main responsible for the appearance of the so called "Sickness behaviour syndrome". Such data is important in recognising that the integrity and functionality of biomolecules is closely connected to the functionality of pure eicosanoid acids (EPA), from both the perspective of nutritional habits and that of therapy for neuropsychiatric illnesses.

Published: 22 April 2010

doi:10.1186/1744-859X-9-S1-S22

Cite this article as: Tsaluchidu: The structure, biosynthesis and functions of EPA: biomolecular neuropsychiatric aspects. Annals of General Psychiatry 2010 9(Suppl 1):S22.

\section{Submit your next manuscript to BioMed Central and take full advantage of: \\ - Convenient online submission \\ - Thorough peer review \\ - No space constraints or color figure charges \\ - Immediate publication on acceptance \\ - Inclusion in PubMed, CAS, Scopus and Google Scholar \\ - Research which is freely available for redistribution \\ Submit your manuscript at www.biomedcentral.com/submit}

